\title{
Avoin korkeakouluopetus ja yleisradio ${ }^{1)}$
}

Korkeakoulujen järjestämä aikuiskoulutus tapahtuu etupäässä avoimen korkeakouluopetuksen ja täyḍdennyskoulutuksen muodossa. Näistä erityisesti avoimella korkeakouluopetuksella on yhtenevyyttä Yleisradion toimintaperiaatteisiin:

- Avoin korkeakouluopetus on tarkoitettu koko aikuisväestölle; osanottajille ei aseteta rajoituksia iän, pohjakoulutuksen, asuinpaikan, ammatin tms. suhteen.

- Avoimen korkeakouluopetuksen tausta-ajatuksena on oikeus elinikäiseen oppimiseen ja koulutuksellinen tasa-arvo.

- Toiminnan vaikuttimena on sivistysyliopiston roolin toteuttaminen tämän päivän maailmassa; avoimen korkeakouluopetuksen avulla korkeakoulu toteuttaa yleissivistys- ja tiedonvälitystehtäväänsä.

Korkeakouluissa on todettu, että avoimen korkeakouluopetuksen kysyntä kasvaa jatkuvasti vuosi vuodelta. Sen myötä on tullut yhä keskeisemmäksi kysymys opetuksen tosiasiallisesta avoimuudesta ja osallistumismahdollisuuksien tasavertaisuudesta.

Edellä kuvattua taustaa vasten voisi olettaa, että avoin korkeakouluopetus ja Yleisradio olisivat löytäneet toisensa. Näin ei kuitenkaan todellisuudessa ole käynyt.

Eri korkeakouluissa on viime vuosina tehty muutamia yhteistyöhankkeita Yleisradion kanssa avoimen korkeakouluopetuksen alueella. Näistä mainittakoon esim. aikuiskasvatuksen, hoitotieteen ja ympäristötieteen radiokurssit. Yhteistyö on kuitenkin ollut melko satunnaista, hankekohtaista ja työnjaoltaan selkiytymätöntä. Sitä on molempien osalta vaivannut henkilö- ja talousresurssien sekä kokonaisvaltaisen, pitkäjänteisen suunnittelun puute.

Tätä taustaa vasten on mielenkiintoista todeta, että kansainvälisesti tänä samana aikana

1) Artikkeli perustuu kirjoittajan Yleisradion seminaarissa 'Yle 1990-luvun aikuiskoulutuksessa' 14.9 .89 pitämään alustukseen. radiota ja televisiota on hyödynnetty korkeakoulutasoisessa aikuiskoulutuksessa laajasti ja tehokkaasti. Tästä ovat hyviä esimerkkejä Englannin Open University, Japanin University of the Air, Kanadassa ja Yhdysvalloissa toteutetut laajamittaiset radio-ohjelmasarjat, Thaimaan kuuluisa avoin yliopisto ja Ruotsin Utbildningsradion tuottama korkeakoulutasoinen opetus.

Näin siis maailmalla, mutta ei meillä. Pitkälti tämä varmasti johtuu siitä, että Suomessa ei ole tehty avoimen korkeakouluopetuksen järjestämisestä yhtenäistä, keskitettyä hallinto- ja rahoitusratkaisua, vaan kaikki korkeakoulut työskentelevät tällä alueella omien vähäisten resurssiensa turvin. "University of the Air" olisi toki periaatteessa mahdollinen ja houkuttelevakin, mutta se vaatisi korkeimman tason koulutuspoliittisen päätöksen, jolla tähän maahan luotaisiin ja resurssoitaisiin yksi valtakunnallinen avoin korkeakoulu.

\section{Muutos on tapahtumassa}

Suomessa on nykyisin avoimen korkeakouluopetuksen alueella havaittavissa selvästi kaksi samanaikaista suuntausta:

- Viestintävälineiden ja korkeakoulujen välillä on virinnyt voimakas kiinnostus yhteistyöhön. Tuore esimerkki on Yleisradion ja Helsingin yliopiston välillä 2.6.1989 tehty puitesopimus, jossa mm. todetaan, että Yleisradio valmistelee yhteistyössä Helsingin yliopiston kanssa suunnitelman avointa korkeakoulua palvelevien radio- ja tv-ohjelmien valmistamisesta ja lähettämisestä. Yleisradion lisäksi yhteistyötä on käynnistetty kaapelitelevisioiden ja paikallisradioiden kanssa.

- Televiestintätekniikka mullistaa aikuiskoulutuksen menetelmiä: audio-opetus, videovälitteinen opetus ja tietokoneen käyttö opetuksessa tulevat olemaan avoimen korkeakouluopetuksen arkipäivää ensi vuosikymmenellä. 
Näistä lähtökohdista on mielenkiintoista jäsentää Yleisradion ja avoimen korkeakouluopetuksen tulevia yhteistyömahdollisuuksia. Käsittääkseni niitä on kolmella tasolla:

\section{1) Avointa korkeakouluopetusta voidaan an- taa siten, että opetus toteutetaan yhteis- työssä Yleisradion kanssa.}

Tällöin on tehtävä ero avoimen korkeakouluopetuksen eri toimintamuotojen kesken:

Suoritustavoitteinen avoin korkeakouluopetus eli arvosanaopetus on aina korkeakoulukohtaista ja sillä on aina vastaavuus jonkin tiedekunnan tutkintovaatimuksiin. Jos tällä alueella lähdetään yhteistyöhön, sitoudutaan pitkäjänteiseen, monivuotiseen työprosessiin. Samalla tulee myös sitoutua siihen, että Yleisradion kautta opetukseen osallistuville taataan opintojen suoritusmahdollisuus. Se taas vaatii valtakunnanlaajuista organisointia, sillä kuulustelujen järjestäminen ja niihin liittyvän hallinnon hoitaminen on tehtävä, jonka suorittamisessa tarvitaan aikuisoppilaitosten apua.

Onkin varmasti perusteltua, että yhteistyö rakennetaan aluksi suosituimpien oppiaineiden varaan ja niissäkin ehkä vain peruskurssitasolle, jolloin opetus todella on tarkoitettu suurelle kohderyhmälle. Korkeakouluissa on monivuotinen kokemus siitä, mitkä aineet pysyvästi siilautuvat suosituimpien joukkoon. Useimmat niistä ovat kasvatustieteellisiä ja yhteiskuntatieteellisiä aineita.

Näissä hankkeissa tulee yhteistyöosapuolten välillä tehdä selvä työnjako: korkeakouluilla on opetuksen sisällön ja toteutuksen vastuu ja asiantuntemus, Yleisradiolla taas ohjelmatekninen vastuu ja asiantuntemus. Molempien osapuolten on myös resurssoitava hanketta nmien vastuualueidensa mukaisesti.

Yleissivistävä avoin korkeakouluopetus, joka ei tähtää opintoviikkosuorituksiin, on nykyisin yleistymässä. Tähän. Alıeeseen. kııılıvat monitieteiset, aikuisopiskelijaa varten suunnitellut korkeakoulutasoiset kurssit ja Studia generalia -tyyppiset luentosarjat. Samoin tähän on luettavissa ns. ikääntyvien yliopistotoiminta, jota tällä hetkellä jo kuusi korkeakoulua maassamme järjestää.

Tällä alueella yhtiestyömahdollisuudet ovat ilmeisesti paljon suuremmat ja helpommin toteutettavissa kuin suoritustavoitteinen opetuksen kohdalla. Samalla voi todeta, että juuri näillä alueilla korkeakouluissa tuotetaan tavattoman tasokasta, ajankohtaista ja yleistajuista opetusta, jolle varmasti riittäisi mielenkiintoa myös luentosalin ulkopuolelle vietynä.

Hyvä esimerkki on Helsingin yliopiston Ikäihmisten yliopisto, jonka toimintaan sisältyy vuosittain $20-25$ monitieteistä luentosarjaa eli yhteensä n. 200-250 asiantuntijaluentoa. Aiheet vaihtelevat vaikkapa geeniteknologiasta ympäristökysymyksiin ja maailman uskonnoista tähtitieteeseen. Luennoitsijoina ovat yliopiston tiedemiehet ja kohderyhmänä 60 vuotta täyttäneet. Luentosarjojen menestys on taattu, mutta sittenkin tuntuu siltä, että potentiaalinen kuulijakunta olisi hyvin paljon suurempi, jos luennot voitaisiin välittää ns. suurelle yleisölle.

Yhteistyömuotona yleissivistävän avoimen korkeakouluopetuksen alueella voi olla joko opetuksen välittäminen suorana lähetyksenä tai esitelmäsarjojen tuottaminen radio- tai televisio-ohjelmiksi em. opetuksen pohjalta.

2) Avoimessa korkeakouluopetuksessa voidaan oheis- ja virikemateriaalina käyttää Yleisradion ohjelmia tai ohjelmatallenteita.

Tätä mahdollisuutta käytetään nykyisin erittäin vähän avoimen korkeakouluopetuksen toteutuksessa. Ilmeisesti korkeakouluissa ei olla tarpeeksi tietoisia Yleisradion ajankohtaisesta opetustarjonnasta tai ohjelmatallenteiden käyttömahdollisuuksista. Lisäksi korkeakouluopetus on perinteisesti kovin luentokeskeistä, jolloin opettajille ei ole syntynyt tottumusta oheis- ja virikemateriaalien jatkuvaan käyttöön.

On kuitenkin syytä todeta, että jo selaamalla Yleisradion opetusohjelmaesitettä voi varmuudella löytää ohjelmia, joilla olisi hyvää käyttöä avoimessa korkeakouluopetuksessa. Tänä vuonna sellaisia ovat olleet esimerkiksi Itämeri-sarja, Suuri kirjalija -sarja sekä geeniteknologiaa ja tähtitiedettä käsittelevät sarjat.

Lisäksi on huomattava, että opetuksessa käytettävän oheis- ja virikemateriaalin ei suinkaan tarvitse olla alunperin opetusta varten tehtyä. Yleisradion ohjelmisto tarjoaa aarreaitan jokaiselle opettajalle, joka haluaa täydentää opetustaan tasokkaalla ja ajankohtaisella ääni- tai kuvamateriaalilla.

Tilanteen muuttamiseksi tarvittaisiin pysyvää tiedotusyhteistyötä Yleisradion ja avoimen korkeakouluopetuksen toteuttajien välillä.

3) Yleisradio voi toimia avoimen korkeakouluopetuksen markkinoijana, antaa tietoiskuja korkeakoulutasoisesta aikuiskoulutuksesta sekä tuottaa ohjelmia, jotka parantavat aikuisten usein puutteellisia oppimisvalmiuksia.

Yleisradion rooliin sopii varmasti koulutuksesta tiedottaminen, mielenkiinnon herättäminen ja kiintoisien teemojen pariin johdattaminen. Tässä avoin korkeakouluopetus voi saada Yleisradiolta arvokasta apua.

Aikuisella on lisäksi usein pitkä tie edessään, kun hän aloittaa opinnot ja "oppii oppimaan". Avoimessa korkeakoulussa hän tarvitsee nopeasti $\mathrm{mm}$. opiskeluteknisiä valmiuksia, menetelmällisiä perustietoja ja kielitaitoa tieteellisen tekstin ymmärtämiseen. Näiden taitojen ja valmiuksien opettamiseen olisi Yleisradio huomattavan tehokas ja joustava väline. 


\section{Käytännön toimenpide-ehdotukset}

Sanoista tekoihin pääsemiseksi teen lopuksi kolme toimenpide-ehdotusta Yleisradion ja avoimen korkeakouluopetuksen yhteistyöstä:

1. Yleisradion ja korkeakoulujen väliset työnjako- ja resurssikysymykset suoritustavoitteisen avoimen korkeakouluopetuksen alueella tehtävässä yhteistyössä selvitetään. Vuosittain käynnistetään 1-2 yhteistyöhanketta.
2. Yleissivistävää avointa korkeakouluopetusta ryhdytään laajasti välittämään Yleisradion kautta. Suoria lähetyksiä kokeillaan ennakkoluulottomasti; kamerat ja mikrofonit tuodaan luentosaleihin ja katsojille tai kuuntelijoille annetaan mahdollisuus osallistua elävään opetustilanteeseen.

3. Yhteydenpitoa korkeakoulujen ja Yleisradion välillä tehostetaan ja siitä tehdään jatkuvaa, säännöllistä ja käytännönläheistä. 